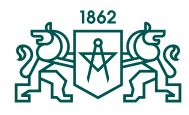

RIGA TECHNICAL UNIVERSITY
No. 5, Sept. 2021, pp. 93-106 https://doi.org/10.7250/HESIHE.2021.005

\title{
VERSATILE PEDAGOGICAL AND SOCIAL ACTIVITIES OF A GRADUATE OF RIGA POLYTECHNIC INSTITUTE JĀNIS STIPRAIS (1870-1946)
}

ALİDA ZIGMUNDE*

Riga Technical University

ELITA STIKUTE

University of Latvia

Summary. The research discusses continuous effort of a pedagogue, economist and journalist Jānis Stiprais (1870-1946) in his pursuit to obtain education and his versatile pedagogical activities in Tomsk (Russia), Tukums, Valka and Riga, as well as the contribution he made in such areas as journalism, folklore and social work. J. Stiprais shared his knowledge of economics gained at Riga Polytechnic Institute (RPI) with the students at the University of Latvia (UL), Latvia People's University and Vilis Olavs Commercial School; in the first half of the 20th century he was the principal of educational institutions in Tukums, Valka and Riga, he also was one of the signatories of the Memorandum of the Central Council of Latvia on 17 March 1944. In the recognition of J. Stiprais merit for Latvia, he was honoured with the highest award of the Republic of Latvia - the Order of the Three Stars.

Keywords: Jānis Stiprais, Riga Polytechnic Institute, signatories of the Memorandum of the Central Council of Latvia, school principals.

\section{Introduction}

Many representatives of the Latvian intelligentsia, including a number of prominent pedagogues, came from Piebalga. It is also a home town of a pedagogue, economist and journalist Jānis Stiprais, who despite his modest financial situation obtained university education and served his people for many years, educating youth.

\footnotetext{
* Corresponding author.

E-mail: alida.zigmunde@rtu.lv

(c) 2021 Alīda Zigmunde, Elita Stikute. Publisher RTU Press.

This is an open access article licensed under the Creative Commons Attribution License

(http://creativecommons.org/licenses/by/4.0/).
} 
Numerous press articles dedicated to J. Stiprais started to appear already during his lifetime. Nowadays, memories about the pedagogue are carefully retained at his Alma Mater. The interest in his highly appreciated contribution may be evidenced by both this research developed in commemoration of the 150th anniversary of J. Stiprais and an article in the RTU newspaper "Jaunais Inženieris» (Young Engineer), published to celebrate his 130th birthday in 2000 [1]. The works translated by J. Stiprais, his books and newspaper articles, as well as the articles dedicated to his personality and heritage published in the periodicals have been preserved in the Latvian libraries, whereas his personal file of a pedagogue, a personal file of a lecturer of the UL, a passport of a citizen of the Republic of Latvia and other documents are stored in the State Historical Archive of Latvia of the Latvian National Archives.

Being a true Latvian patriot, J. Stiprais signed the Memorandum of the Central Council of Latvia in 1944. One of the latest publications about J. Stiprais is his biography, which is included in the biographical dictionary dedicated to the signatories of the Memorandum published in 2014 [2]. It should be noted that some inaccuracies have been made while compiling the mentioned biography of J. Stiprais, since neither the original documents nor his Curriculum Vitae were used - the name of his father was spelled incorrectly, the years of his pedagogical activity were also not recorded accurately. The aim of the present research is to study pedagogical and social activities of J. Stiprais and to clarify his biographical data. The main research method used in this paper is analysis of literature sources.

\section{Childhood, School and Study Years of Jānis Stiprais}

Jānis Stiprais was born in Vecpiebalga Parish on 31 August 1870. His birth was registered with the Congregation of Piebalga, his father Andžs was a farmer [3]. This is also confirmed by J. Stiprais autobiography written in the early 20th century [4]. Later, in some documents, including the passport of the Republic of Latvia, the name of J. Stiprais father was recorded as Antons [5], this name later also appeared in several published pieces of research [2].

For two years, Jānis studied at Kaibēni School, educators and writers brothers Matiss (1839-1920) and Reinis (1848-1926) Kaudzites were his first teachers. Then for four years he studied at Skujene Parish School, then - at Tsar Peter I Vocational School in Riga, which he graduated in 1892. Jānis' father passed away when he was in the 4th grade of the vocational school and thus Jānis had to provide for himself. Jānis was 
exempt from paying tuition fees at the vocational school, however, he had to pay apartment rent. He could not timely cover it and thus accumulated debts. To settle his obligations, he started to give private classes to the host's children and later to other children. Studying in the 5 th grade of the vocational school, teaching private pupils J. Stiprais earned a considerable amount of money for that time -10 roubles per month. He soon also earned a job as a transcriber for a district court translator. It was not easy, because he often delivered four private lessons a day and returned to the rented apartment only after nine o'clock in the evening. In the absence of private lessons, he wrote for newspapers and translated for money [4].

In September 1892, J. Stiprais entered the Department of Agriculture of Riga Polytechnicum, but in 1893, he had to interrupt his studies due to material considerations - he had to pay for his studies at a private university. For the next six years, he worked and saved money for education. In the autumn of 1899 , J. Stiprais resumed his studies at Riga Polytechnic Institute (RPI), which had been reorganized in 1896, this time choosing to study at the Department of Commerce [6]. In his spare time, he continued working as a tutor, as well as earned money by selling firewood. After gaining some knowledge of trade, J. Stiprais began to teach it to others, and later established private trade courses [4]. As a student, in 1892 J. Stiprais joined the oldest Latvia-based corporation of the Latvian students «Selonija», he later worked in its Society of Philistines. J. Stiprais graduated from RPI in 1904, in the same year as the Latvian public figure and publicist Vilis Olavs (1867-1917). It is interesting to note that later J. Stiprais worked in the school named after Vilis Olavs.

\section{Translations, Journalism, Compilation of Folklore}

Already during his university years at the end of the 19th century, J. Stiprais earned his living by translating. For example, he translated a book «Edisons» by the Russian writer and translator Andrei Kamensky (Андрей Васильевич Каменский; 1843-1913) from Russian. It was published in 1892 by the Department of Useful Books of the Riga Latvian Society [7]. It is quite possible that J. Stiprais translated the autobiography of an American inventor and entrepreneur Thomas Alva Edison (1847-1931) not only for financial reasons, but also out of personal interest, since he was studying engineering.

The translations from the German language by J. Stiprais should be also named - the tragedy «Marija Stjuarte» (Maria Stewart) by the German poet and playwright Friedrich Schiller (1759-1805) and the 
drama «Fricitis» by the writer Hermann Sudermann (1857-1928). Both plays were staged - in 1896, the theatre of Riga Latvian Society performed «Marija Stjuarte» and in 1904, Riga New Theatre staged «Fricitis».

Already during his study years, J. Stiprais collaborated with almost all newspapers that were published in Latvian at that time. In his autobiography, J. Stiprais wrote that during the summer holidays of 1902, he headed the Foreign Section of the newspaper «Baltijas Veestnesis» [4]. Later he worked as a collaborator in the newspapers «Dzimtenes Vèstnesis», «Lìdums», "Tautas Balss» and from 1919 to 1940, in the newspaper «Brīvā Zeme».

In 1908, J. Stiprais' article «Mūsu tirdzniecības mācību iestādes» (Our Trade Educational Institutions) was published in the newspapers «Dzimtenes Vēstnesis» [8] and "Zemkopis» [9]. It discussed the history of these schools in the Russian Empire, which at that time included the territory of the present-day Latvia, legislation for their establishment and operation, and popularity, as trade was considered by J. Stiprais to be the cornerstone of the well-being of the Latvian people. He also mentioned his Alma Mater - RPI, whose future graduates of the Department of Commerce started working already during their studies, working in shops as accountants, holding responsible positions at the banks and in trade, receiving good salaries. Prospective entrepreneurs also used to teach languages, but at that time it was a highly competitive field, so remuneration was rather low. However, J. Stiprais was a selfless pedagogue who primarily worked for the sake of a noble idea rather than due to monetary considerations.

In the 1920s and 1930s, J. Stiprais also published various articles in periodicals, including reflections on schooling and childrearing. For example, with regard to the choice of schools, J. Stiprais wrote to parents that a good education can be obtained not only in big cities. He noted that if farmers opt to send their children to study in the city, as a result, children may not only lose connection with their parents as well as the love of the countryside, the parents may also lose control over their children's use of leisure time and the process of education. Based on observations of J. Stiprais, in large schools, where the number of pupils is about a thousand, «a rare teacher knows his pupils by name» [10].

J. Stiprais considered education one of the basic values in life. Having acquired education himself, he wanted to make sure as many people as possible obtain it as well. His pursuit of education and spiritual values came from the family and society where he spent his childhood - Piebalga, Vidzeme, where the ideas of fraternal congregations were widespread. Brothers Kaudzite, who maintained close connections with the fraternal congregations and their pupils at Kaibēni School, also 
played a major role in this regard. As J. Stiprais wrote in his memoirs, they «not only gave knowledge but also the laid down foundations of morality», made pupils accustomed to work and order, instilled a desire to pursue noble goals [11]. J. Stiprais sticked to these values throughout his life and had always spoken well about both brothers-teachers, who were excellent pedagogues and educators able to engage pupils also in their free time, for example, doing sports. There was a self-built skating rink near the school, the skates were mostly homemade - with a blade driven and secured in a wooden block, which was either a self-wrought scythe or some other suitable piece of iron. There were no enough homemade skates for everyone, many skated with one skate or borrowed the other skate from others. Pupils also skied and rode on the sleds. The teachers - brothers Kaudzite - also went into sports. For example, Matīss Kaudzite had «light metal skates that could be attached with a screw to the heel of the boot» [12]. The children rode from the hill with a single ski made of aspen wood by local craftsmen. Pupils called skis luǵes. They were shorter and wider than those we use today. The pupils neither knew nor used ski poles. On the other hand, the pupils held ropes tied to the front of each ski, which made it possible to change the direction of the ride or, when descending the mountain, they helped to maintain balance [12].

J. Stiprais loved to get involved in the discussions about science, art, literature, ethics, noble goals, tasks and success. This is evidenced by his article «Vienkāršība dzīvē un audzināšanā» (Simplicity in Life and Upbringing) published in 1923 [13]. He also pointed at the negative social phenomena, such as extravagance, revelry, and pursuit of wealth. From a young age, he believed that people should not be divided into rich and poor, and that regardless of their descent and material status, people can sit at the same table side by side. Even as a young man, J. Stiprais called for abstinence from alcohol abuse and exaggeration in clothing. He reported on these issues at an event organised by the Society of Philistine (Senior Members) of «Selonija» on 14 January 1929 [14]. His report was titled «Vienkārš̄iba dzīvē un audzināšanā» (Simplicity in Life and Upbringing), it was copied and sent to all active members of Latvian corporations. J. Stiprais discussed the above-mentioned issues pointing out that the money earned should be spent prudently and evenly, the family and the school should increase the level of morality of young people. The pedagogue, economist and journalist said in his report, «Academically educated citizens should not follow in the footsteps of unbalanced bacchanals and follow their lead, take them as a paragon for themselves and waste their hard and honestly deserved possessions. The peoples belonging to the culture of Western Europe do not practice wasteful revelry and excessive eating and drinking that continue
Versatile

Pedagogical and Social Activities of a Graduate of Riga Polytechnic Institute

Jānis Stiprais (1870-1946) 
until the next morning, undermining their health and impairing their ability to work. We have inherited these entertainment habits from the east. Such lifestyle is not suitable for our circumstances, because a person may spend more than one's monthly income during a single evening» [15]. At the end of the report, J. Stiprais summoned, «Let's teach simplicity and thriftiness not only with words, but with all our lives, then the new generation, nation and society will follow the set standard and live up to an excellent example» [15].

J. Stiprais also made a considerable efforts, compiling Latvian folk tales, legends and stories. A book publisher, social figure and patron Jānis Rauska (1873-1967) published «Latviešu tautas pasakas» (Latvian Folk Tales; 1918) at a publishing house in Valka. This carefully collected and compiled edition was then re-published in seven volumes (1921). «Latviešu tautas teikas un nostāsti» (Latvian Folk Tales and Stories; 1921), which came from the collections of the Latvian writer, folklorist, researcher, social figure and teacher Ansis Lerhis-Puškaitis (1859-1903) was also published there. This volume comprised the stories about the origin of the Daugava River, the king of snakes, Piebalga Pub, the origin of Ranka and Pakuli Lakes, Vecpiebalga Castle, and many other. J. Rauska also published «Tautas teikas un pasakas 1. dala. Dievs, Pērkons, Velns» (Folk Tales and Fairy Tales Part 1. God, Thunder, Devil; 1925).

\section{Pedagogue's Work}

J. Stiprais became acquainted with the profession of a pedagogue in 1893. After he had to discontinue his studies, he worked for one year both as a private teacher and as a teacher at a private girls' school in Kandava, then for two years - as a private teacher in Valmiera at the home of a writer and Pastor of the Valmiera St. Simon Congregation, Jānis Neilands (1840-1915), then for three years - as a teacher in Jaungulbene [16]. Later, he worked as a teacher near Ikšksile, teaching the sons of two manufacturers, preparing them for enrolment in a vocational school [4]. While he studied at the university, he was involved in the pedagogical activity teaching to the private pupils. In 1904, immediately after his graduation, he went to Russia and began working as a teacher at a stock exchange commercial school and trading evening courses in the Siberian city Tomsk. In 1906, the young engineer returned to Latvia and in August began working as an inspector at Tukums School of Commerce. From 1909 to 1918, he was the Principal of that school. Arnolds Zarinš (1876-1940), a graduate (1907) of the Department of Chemistry of RPI, who had previously worked as the Secretary of the Tukums City, taught merchandising, chemistry and natural sciences at the School 
of Commerce. Jékabs Vìtols (1877-1961), a graduate (1907) of the Department of Engineering of RPI [17], taught mathematics and physics. Principal J. Stiprais knew A. Zarinš and J. Vittols since his study years, because they together worked at the student corporation «Selonija». During World War I, the School of Commerce continued working in Valka and in 1918, it was closed. Then for two years - from 1918 to 1920 J. Stiprais worked as the Principal of Valka Latvian Secondary School. Then in 1920 he returned to Kurzeme and for two years he was the Principal of Tukums City Secondary School [18].

Figure 1. Jānis Stiprais (c. 1920).

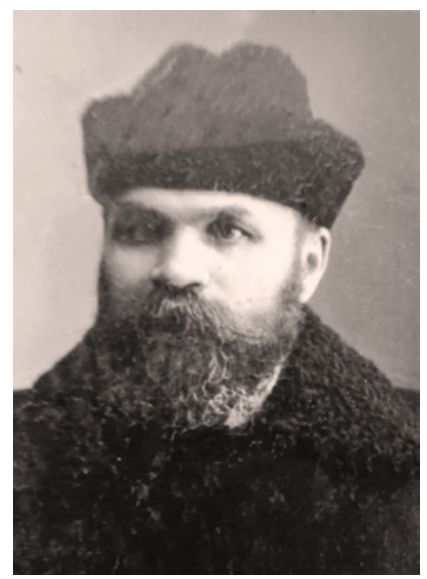

In 1922, J. Stiprais started to run the Riga City Secondary School No. 1, and from 1929 - the Gymnasium (now - Riga State Gymnasium No. 1). When he started working as a principal in Riga, he already knew some teachers. For example, Juris (Georgs) Lerhs (1881-1967), who had taught mathematics at Tukums School of Commerce. While performing the duties of the Principal, J. Stiprais, being a good psychologist, was able to resolve conflicts and reconcile the parties to the conflict. He managed to maintain unshakable inner peace and prudent composure. One of the graduates of 1927, later a poet Leonids Breikšs (1908-1942), believed that Principal J. Stiprais knew all his pupils as if they were his own children [19]. Although he was strict, the pupils respected and appreciated him. When the students were caught doing something naughty or misbehaving, he asked, «Boys, is it really the way you should behave?» [19]. He expressed serious and though over wishes and kind words of encouragement to the graduates of the school. In 1934, J. Stiprais left the Gymnasium. His position of the Principal of Riga City Gymnasium No. 1 was taken over by a public official, diplomat, pedagogue, theologist, and journalist Pauls Oto Gailitis (1869-1943) [20], 
a brother of Markus Gailitis (1882-1942), a graduate (1911) of the Department of Engineering of RPI.

The family of Riga City Gymnasium No. 1 was not too happy about the departure of Principal J. Stiprais. The poem «Dir[ektoram] J. Stiprais kungam aizejot» (To Dir[ector] J. Stiprais on His Departure) written by a pupil, later a veterinarian Andrejs Šmitmanis (1915-2004) may be seen as a proof of respect and recognition J. Stiprais deserved among his pupils:

You loved new pupil generations,

Which every year came in troops.

And now we want to warmly praise you,

In our First Gymnasium rooms.

You are school's father and the guardian,

For whom every pupil is dear and good,

And yet you're leaving for another job,

Your name here will stay grand and great!

We see you with a youthful vigour

Walking only where your duty calls;

But your work and thoughts will be devoted

Forever to the new generations of Latvian schools.

And now, parting from our school,

You will leave, but your work will stay alive.

Recalling this, new generations will repeat:

«You - First Gymnasium's First Kriwe!» [21].

In 1934, J. Stiprais was entrusted with the organization and management of the new Riga City V. Olavs School of Commerce. Exactly for this reason, J. Stiprais had to resign from the position of the Principal of Riga City Gymnasium No. 1. J. Stiprais worked as the Principal of V. Olavs Commercial School only for a couple of years and already in 1935/1936 retired during the academic year [22].

In addition to pedagogical work at school, J. Stiprais had been working as a lecturer at the University of Latvia since 1922, teaching Business Correspondence in Latvian and German and Introduction to Cooperative Business [23]. He continued this work at the University also after retirement. He also taught Business Correspondence in Latvian at the Latvian People's University [24]. J. Stiprais also delivered lectures at Krišjānis Barons Folk University [25].

J. Stiprais made a considerable contribution to development of textbooks. He compiled a self-study German language handbook, providing learner the opportunity to learn grammar and some useful 
words, which was published by J. Rauska Publishing House in Valka in 1918. The handbook contained sample conversations, trade letters and petitions, and texts for reading. In 1919, two ABC books for primary schools were published - «Strauts: mazā ābece» (Strauts: Little ABC) and «Strauts: ābece» (Strauts: the ABC). His book «Strauts: lasāma grāmata pamatskolām» (Strauts: A Book For Primary Schools) in four parts (19231926) was also published in Valka. The first part of this book was printed for the second time - in 1929 in Riga. The book about ancient times by J. Stiprais about Rome and Carthage was aimed at providing additional knowledge in history, it was published by J. Rauska Publishing House in 1927.

The learning aid for the secondary school course in social sciences «Pamatjēdzieni par valsti un tiesībām» (Basic Concepts of the State and Law) was first published by J. Rauska Publishing House in 1924, the second edition was published in 1927. The third, fourth and fifth revised editions of this book were published in Riga in the 1930s. The textbook «Tirdzniecības korespondence» (Business Correspondence; 1921, 1930, 1938), as well as «Tirdzniecības un rūpniecības veikalvedība» (Trade and Industrial Store Management; 1936), «Tirdzniecības vēstuḷ metodika» (Methodology of Business Letters; 1937), which were intended for future entrepreneurs, were published several times in Riga.

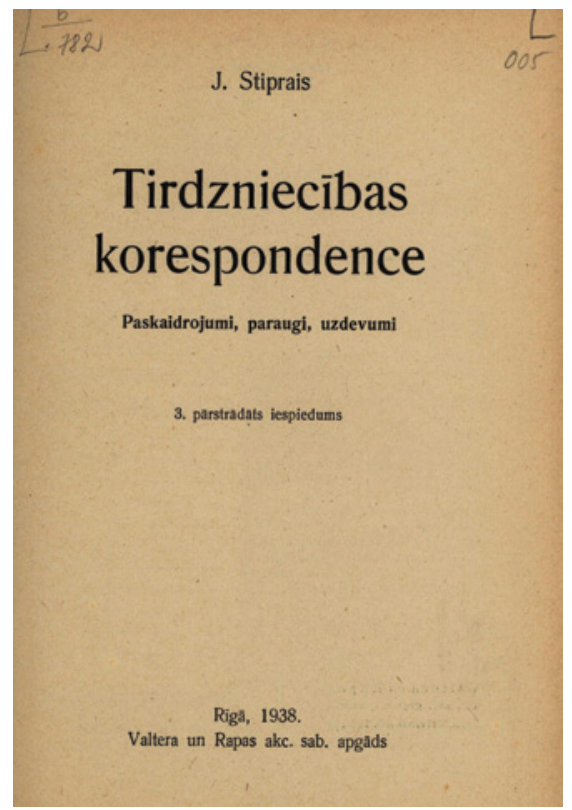

Figure 2. The Cover of the book by J. Stiprais «Tirdzniecības korespondence» (1938).

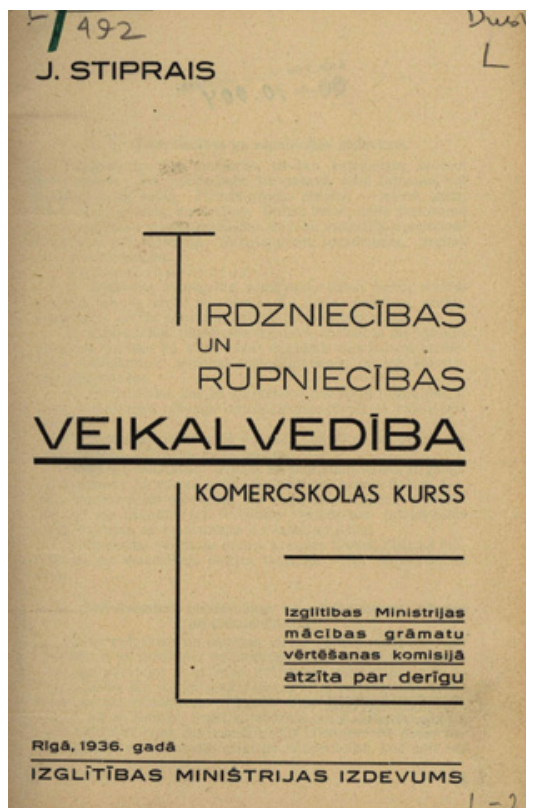

Figure 3. The Cover of the book by J. Stiprais «Tirdzniecības un rūpniecības veikalvedība» (1936).
Versatile

Pedagogical and Social Activities of a Graduate of Riga Polytechnic Institute

Jānis Stiprais (1870-1946) 


\section{Social Activities}

J. Stiprais, a pedagogue, economist and journalist, is often referred to as a social and cultural worker [22]. He worked at the Society for the Promotion of the League of Nations (LN) founded in Latvia in 1923. The aim of the Society was to promote the development and further establishment of the LN, to support Latvia in this organization, and to popularize the ideas and tasks of the LN in Latvia. The LN was the most important international organization after World War I, the predecessor of the United Nations. Jānis Čakste (1859-1927) was one of the founders of the promotion society [26].

Significant and versatile contribution of J. Stiprais to social and educational spheres in Latvia was highly appreciated - in 1926, he was awarded the Order of the Three Stars of the 4th class. He received the Cross of Honour of this organization for his work in the main board of the Latvian Red Cross. J. Stiprais worked in this organization together with an engineer, RPI graduate (1901), selonian ${ }^{1}$ Spricis Paegle (18761962), and his colleagues from the University of Latvia - doctors, professors Kārlis Barons (1865-1944) and Ernest Putniņš (1867-1962), as well as many other prominent Latvians [27].

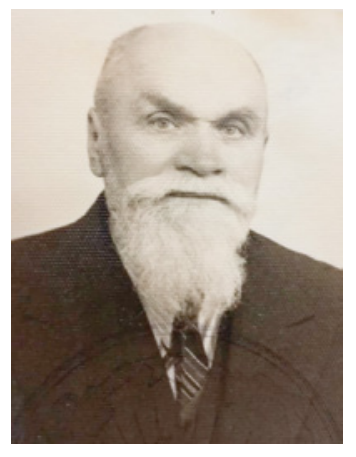

Figure 4. Jānis Stiprais (1940s).

J. Stiprais spent the end of his life and the years of World War II in Latvia. He advocated the restoration of the independence of the Republic of Latvia and was one of the signatories of the Memorandum of the Central Council of Latvia drawn up on 17 March 1944 [2].

\section{Conclusions}

Jānis Stiprais, a pedagogue, economist, journalist and social figure, was «the most prominent personality, an extraordinary figure at the school he managed for twelve and a half years during the existence of

\footnotetext{
${ }^{1}$ Member of the student corporation «Selonija»
} 
Riga City Gymnasium No. 1» in the first half of the 20th century [28], a God-given talent [29]. He is one of the RPI graduates who disseminated the knowledge he gained at the university to his students in commercial schools, gymnasiums and universities both as a pedagogue and as the author of textbooks for future entrepreneurs, reading books for primary schools and social science textbooks for secondary and gymnasium students. Thanks to our knowledge and love for the work of pedagogues, we still remember J. Stiprais now, more than seven decades after he passed away. His legends, fairy tales and stories of Latvian folk retain their cultural and historical value.

In the course of the research it was clarified that although two different names of $J$. Stiprais father appear in different documents Andžs [30; p. 64] and Antons [2, 5], mistakes were not made, because already during studies at RPI it was found that the father is called both Andžs and Antons [18; p. 2]. J. Stiprais ran the Riga City Gymnasium No. 1 until 1934 instead of 1935 [2]. J. Stiprais, a teacher, economist and journalist, had passed away not on 26 April 1946 [30; p. 88], but on 30 April, which has so far been mentioned as the date of death, apparently buried in the Forest Cemetery in Riga.

J. Stiprais had two sons. His elder son died at the early age, while learning at school, his younger son - Pèteris Stiprais (1913-1947) - was a medic, he died and was buried in Germany. J. Stiprais' wife Marija Stiprā (1884-1963) was also a teacher.

\section{REFERENCES}

[1] Zigmunde, A. Pedagogam Jānim Stiprajam - 120. Jaunais Inženieris, 2000. gada 28. septembris, Nr. 3, 9. Ipp.

[2] Kvāle, I. (sast.). Ar parakstu par Latviju: biogrāfiskā vārdnīca: Latvijas Centrālās Padomes Memoranda parakstītāju biogrāfijas. Rīga: Latvijas Kara muzejs, 2014, 239. lpp.

[3] Piebalgas draudzē 1870. gadā dzimušo saraksts. Latvijas Nacionālā arhīva Latvijas Valsts vēstures arhīvs (turpmāk - LNA LVVA) 235. f., 4. apr., 2719. l., 13. lp.

[4] Graudiñš, K. (sast.). Selonijas albums, 1880-1905. Jelgava: G. Landsbergs, [1905], 245.-246. lpp.

[5] Jāṇa Stiprā Latvijas Republikas pase. LNA LVVA 2996. f., 17. apr., 47347. l., 1.lp.

[6] Studentu reǵistrs. LNA LVVA 7175. f., 1. apr., 1904. l., 103. lp.

[7] Kamenskis, A. V. Edisons (tulk. J. Stiprais). Rīga: R.L.B. Derīgu grāmatu nodalıa, 1892, 47 lpp.

[8] Stiprais, J. Mūsu tirdzniecības mācību iestādes. Dzimtenes Vēstnesis, 1908. gada 18. augusts, Nr. 190, 1. lpp. 
[9] Stiprais, J. Mūsu tirdzniecības mācību iestādes. Zemkopis, 1908. gada 27. augusts, Nr. 35, 727.-728. lpp.

[10] Stiprais, J. Skolas izvēle. Brīvā Zeme, 1922. gada 22. augusts, Nr. 186, 1. lpp.

[11] Stiprais, J. Skolēnu atmiṇas par brāḷiem Kaudzītēm. Brīvā Zeme, 1923. gada 17. oktobris, Nr. 231, 5. lpp.

[12] Stiprais, J. Brāḷi Kaudzītes un skolēnu ziemas sports. Fiziskā audzināšana: rakstu krājums. 1. sēj. Rīga: Latvijas fiziskās audzināšanas darbinieku biedrība, 1931, 24.-26. lpp.

[13] Stiprais, J. Vienkāršība dzīvē un audzināšanā. Brīvā Zeme, 1923. gada 13. janvāris, Nr. 10, 5. lpp.

[14] Stiprais, J. Vienkāršība dzīvē un audzināšanā. Rīga, 1929, 8. lpp.

[15] Studentu korporācijas «Selonija» filistru biedrības filistru referāti. LNA LVVA 4261. f., 1. apr., 58. 1., 71. lp.

[16] G̣imnāzijas direktora J. Stiprā 25 gadu darba jubileja. Latvis, 1929. gada 12. oktobris, Nr. 2394, 6. lpp.

[17] Zvaigzne, A. Tukums un Tukuma skolas. Tukums: Bijušā Tukuma apriṇķa un pilsētas skolas audzinātāju un audzēknnu biedrība,1934, 196. lpp.

[18] Skolotāja Jāṇa Stiprā personāllieta. LNA LVVA 1632. f., 1. apr., 20 102. l.

[19] Šmits, A. Audzinātāja Jāṇa Stiprā piemiṇai. Latvija, 1947. gada 29. jūlijs, Nr. 55, 3. lpp.

[20] Veraenderung in der Leitung der Rigaer Mittelschulen. Riga am Sonntag, 5. August 1934, Nr. 402, S. 1.

[21] Šmitmanis, A. Dir. J. Stiprais kungam aizejot. Magazina, 1934. gada 17. augusts, Nr. 118, 6. lpp.

[22] Dir. J. Stiprā 65 gadi. Tēvijas Sargs, 1935. gada 30. augusts, Nr. 35, 6. lpp.

[23] Lektors Jānis Stiprais. Latvijas Universitāte, 1919-1929. Rīga: LU, 1929, 568. lpp.

[24] Latvijas Tautas universitāte. Jaunākās Ziṇas, 1936. gada 12. septembris, Nr. 207, 29. lpp.

[25] Kr. Barona tautas Augstskola. Jaunākās Zingas, 1937. gada 14. janvāris, Nr. 10, 6. lpp.

[26] Treijs, R. Latvija un pirmā globālā starptautiskā organizācija. Latvijas Vēstnesis, 2001. gada 21. septembrī, Nr. 134,11. lp.

[27] Galvaspilsētas ziṇas. Jaunākās Ziṇas, 1940. gada 30. martā, Nr. 71, 9. lpp.

[28] Seglenieks, N. Jānis Stiprais, direktors 1921-1934. Rīgas pilsētas 1. ǵimnāzija: rakstu krājums, 1984, 313. lpp.

[29] Ievērojamam audzinātājam pensijā aizejot. Skolu Dzīve, 1936. gada janvāris-februāris, Nr. 1/2, 15. lpp.

[30] Latvijas Universitātes mācībspēka Jāṇa Stiprā personāllieta. LNA LVVA 7427. f., 13. apr., 1636. l., 66., 88. lp.

\section{SOURCES OF ILLUSTRATIONS}

Figure 1. Jāṇa Stiprā Latvijas Republikas pase. LNA LVVA 2996. f., 17. apr., 47347. 1., 1. lp. 
Figure 2. Latvijas Nacionālā bibliotēka.

Figure 3. LNB.

Figure 4. Latvijas Universitātes mācībspēka Jāṇa Stiprā personāllieta. LNA LVVA 7427. f., 13. apr., 1636. 1., 64. lp.

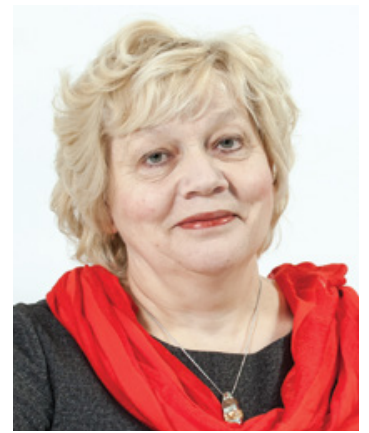

ALĪDA ZIGMUNDE, Dr. paed., Mg. phil., has been a Specialist at the Museum of Riga Technical University since 1989. From 2007 to 2015, she was a Senior Researcher. She is currently a Professor with the Institute for Humanities and the Head of the Department for Historic Research and Scientific Publications of the RTU Research Centre for Engineering History. Her main academic interests include the history of pedagogy in Europe, history of the institutions of education, and history of engineering sciences and universities.

Address: 1 Kronvalda Boulevard, Room 203, Riga, LV-1010, Latvia

Phone: +371 29869642

E-mail: alida.zigmunde@rtu.lv

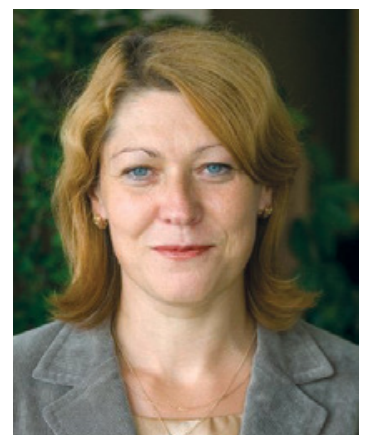

ELITA STIKUTE, Dr. paed., Assistant Professor at the Faculty of Pedagogy, Psychology and Art, University of Latvia, teacher of the Latvian language and literature at Riga Centre Language School. Research fields: school pedagogy; critical thinking approach to learning; history of pedagogy: history of methodology of literature teaching, history of personalities - methodologists in the Latvian literature and language teaching. The author of more than 35 academic articles and a monograph «Didactics of Latvian Literature» (2011). Expert at Latvia's Council of Science in the field of Educational Sciences (2014-2018). Member of the Education Terminology Subcommittee, Baltic Association of Historians of Pedagogy, and the Association of Latvian Language and Literature Teachers, mentor of higher education and school pedagogy, expert and developer of teaching aids within the project «School 2030». In 2018, she was awarded the «Golden Pen» by Riga City Council for her contribution to school pedagogy.
Versatile

Pedagogical and Social Activities of a Graduate of Riga Polytechnic Institute

Jānis Stiprais

(1870-1946)

Address: 1 Imantas 7. linija, Riga, LV-1083, Latvia

Phone: +371 26414041

E-mail: elita.stikute@lu.lv 


\section{Rīgas Politehniskā institūta absolventa Jāṇa Stiprā (1870-1946) daudzpusīgā pedagoǵiskā un sabiedriskā darbība}

Pētījumā atklāta pedagoga, tautsaimnieka un žurnālista Jāṇa Stiprā (18701946) mērktiecība, lai iegūtu izglītību un viṇa daudzpusīgā pedagoǵiskā darbība Tomskā (Krievijā), Tukumā, Valkā un Rīgā, ieguldījums žurnālistikā, folklorā, sabiedriskajā darbā. J. Stiprais ar Rīgas Politehniskajā institūtā (RPI) iegūtajām zināšanām ekonomikā dalījās ar studentiem Latvijas Universitātē, Latvijas Tautas universitātē un Viḷa Olava komerckolā, 20. gadsimta pirmajā pusē bija mācību iestāžu direktors Tukumā, Valkā un Rīgā, darbojās latviešu studentu korporācijā «Selonija», bija viens no 1944. gada 17. marta Latvijas Centrālās Padomes Memoranda parakstītājiem. J. Stiprā nopelni Latvijas labā novērtēti ar Latvijas Republikas augstāko apbalvojumu - Triju Zvaigžnu ordeni.

Atslēgas vārdi: Jānis Stiprais, Rīgas Politehniskais institūts, Latvijas Centrālās Padomes Memoranda parakstītāji, skolu direktori. 